This item was submitted to Loughborough's Research Repository by the author.

Items in Figshare are protected by copyright, with all rights reserved, unless otherwise indicated.

\title{
Marketing outsourcing in the English Premier League: the rights holder/agency interface
}

PLEASE CITE THE PUBLISHED VERSION

http://dx.doi.org/10.1080/16184742.2017.1314530

\section{PUBLISHER}

Taylor \& Francis @ European Association for Sport Management

\section{VERSION}

AM (Accepted Manuscript)

\section{PUBLISHER STATEMENT}

This work is made available according to the conditions of the Creative Commons Attribution-NonCommercialNoDerivatives 4.0 International (CC BY-NC-ND 4.0) licence. Full details of this licence are available at: https://creativecommons.org/licenses/by-nc-nd/4.0/

\section{LICENCE}

CC BY-NC-ND 4.0

\section{REPOSITORY RECORD}

Manoli, Elisavet, and lan Hodgkinson. 2019. "Marketing Outsourcing in the English Premier League: The Rights Holder/agency Interface”. figshare. https://hdl.handle.net/2134/24470. 


\title{
Marketing Outsourcing in the English Premier League: The Rights Holder/Agency Interface
}

\author{
Submitted to: European Sport Management Quarterly
}

\author{
Argyro Elisavet Manoli ${ }^{1}$ \\ (Corresponding Author) \\ School of Sport, Exercise and Health Sciences \\ Loughborough University \\ Email: E.A.Manoli@lboro.ac.uk
}

\begin{abstract}
Ian R. Hodgkinson ${ }^{2}$
School of Business and Economics

Loughborough University

Email: I.R.Hodgkinson@lboro.ac.uk
\end{abstract}

${ }^{1}$ School of Sport, Exercise and Health Sciences, Loughborough University, Leicestershire LE11 3TU, UK. Tel: +44 (0)1509 228453.

${ }^{2}$ School of Business and Economics, Loughborough University, Leicestershire LE11 3TU, UK. Tel: +44 (0)1509 223865. 


\title{
Marketing Outsourcing in the English Premier League: The Right Holder/Agency Interface
}

\begin{abstract}
Research question: While marketing outsourcing may offer a clear means for revenue generation and cost efficiency, there is a need to go beyond the outsourcing decision itself to address 'how' outsourcing can be managed successfully. Differing to existing studies, this study examines the dynamic nature of marketing outsourcing from the right holder and agency perspectives in an overlooked setting.

Research methods: Qualitative data was generated from semi-structured interviews with marketing managers from 30 English Premier League (EPL) football clubs and with 10 marketing agency account managers. The clubs included in this study had all participated in the EPL, and all ten marketing agencies interviewed had been contracted at some point in time to these clubs.
\end{abstract}

Results and findings: By capturing both sides of the right holder/agency interface, this study includes a neglected perspective (i.e. agency) to more accurately examine the principal-agency relationship in marketing outsourcing. The findings add greater nuance to the drivers/motivations and barriers/constraints that are typically cited in sport management and marketing studies, providing a new framework to understand the relationship dynamic and guide successful sport marketing outsourcing initiatives. Implications: Though outsourcing can be an impactful business decision, the success of marketing outsourcing in football is dependent upon the balance of conditions across the right holder/agency interface. Specifically, while pushing factors may contribute to effective marketing outsourcing, resisting factors undermine the right holder-agency relationship. However, in nurturing key necessary features both parties can limit resisting factors and emphasise push factors for shared value creation. Keywords Marketing outsourcing; Agency theory; English Premier League, Right holder; Marketing agency. 


\section{Introduction}

In sport organisations marketing practices are drivers of successful business performance (Brooksbank, Garland, \& Werder, 2012), but these organisations have a decision to make: perform marketing in-house or outsource this function. Otherwise referred to as the 'make or buy' decision, outsourcing is when 'one or more person(s) hires another person(s) to perform a service' (Bouchet, 2010, p. 278). This often takes the form of externalising certain business functions to an external agent, which has been reported to increase firm flexibility (Quinn, 1999), deliver cost efficiency (Bouchet, 2010), provide specialisation (Lee, 2016), enhance revenue generation (Lee, Oh, \& Juravich, 2016), and secure competitive advantages (Kotula, Ho, Dey, \& Lee, 2015). However, there are potential pitfalls and dangers to an outsourcing strategy, such as choosing the wrong partner, overlooking personnel and cost issues, and a failure to recognise business risks (Barthélemy \& Adsit, 2003; Bonifazi \& Desouza, 2004), resulting in many organisations insourcing their marketing functions. Nevertheless, sport organisations continue to hire third party companies to manage their merchandising, concessions, sales, and customer service functions (Lee \& Walsh, 2011; Lee et al., 2016; Walker, Sartore, \& Taylor, 2009) and thus marketing outsourcing is highly prevalent in this context (Bouchet, 2010; Lee et al., 2016; Walker, Sartore, \& Taylor, 2009). So rather than avoiding this strategic option the question arising for sport organisations is how to manage marketing outsourcing effectively?

Since motivations for outsourcing include 'cost reduction, focus on core activities, access to resources/skills, performance improvement, innovation, and development of employees' (Lee, 2016, p. 14), it is viewed by sport organisations as having a fundamental role in their economic value (Bouchet, 2010; Campos, 2002; Lee et al., 2016). Adopting marketing outsourcing strategies for performance gains resonates particularly with professional football clubs (e.g. 
Couvelaere \& Richelieu, 2005) given their poor financial performance and relative smallness (Deloitte, 2015). However, while marketing outsourcing may offer a clear means for revenue generation and simultaneous cost effectiveness (Lee \& Walsh, 2011), there is a need to go beyond the outsourcing decision itself to address 'how' outsourcing can be managed successfully (Yang, Wacker, \& Sheu, 2012). This places the agency relationship under the spot light and particularly the divergent interests between the parties involved (Lee \& Walsh, 2011), which may carry implications for marketing outsourcing effectiveness and the creation of shared value.

Knowledge and understanding about the outsourcing relationship in sport remains in its infancy (Lee \& Walsh, 2011) with efforts largely concentrated on the reasons for organisations choosing to outsource (e.g. Williams \& Macdonald, 2015). There is then a lack of understanding of both the dynamic nature of the right holder-agency relationship (Lee et al., 2016) and how agents approach the marketing outsourcing interface (Walsh \& Lee, 2012). To address these knowledge voids, this research draws on agency theory to examine the drivers and barriers that influence the outsourcing relationship from the right holder and agency perspectives. This study is set at the interface of business-to-business (hereafter B2B) marketing outsourcing between professional football clubs and marketing agencies in England. In doing so, we diverge from existing outsourcing studies, which typically prioritise the principal's perspective, by examining 'how’ outsourcing can be managed successfully across the right holder/agency interface. This approach is consistent with a need to view marketing agencies not as 'contractors that need to be controlled but as partners that can create shared value over the long term’ (McGovern \& Quelch, 2005, p. 23).

The article is structured as follows: first the principal-agent relationship in sport marketing outsourcing is reviewed and the features of existing studies considered. Next, the 
research setting and methodology adopted are outlined. Then, findings and discussion are intertwined to assess the dynamic nature of the right holder-agency relationship from both sides of the marketing outsourcing interface. To conclude, results and implications are considered in light of the study's limitations, with a future research avenue highlighted.

\section{Sport marketing outsourcing}

The contention is made in the sport management literature that 'there are two major outsourcing motivations: cost-driven and performance-driven (Lee, 2016, p. 14), and though valid, this belies the complexities of the sport marketing outsourcing interface.

With regard to outsourcing in sport, there is a general understanding that this refers to the use of intermediaries or agencies that act on behalf of a 'sports property' and might include activities such as licensing and merchandising, sale of media advertising and venue advertising, and sales of ‘official sponsorship’ rights to corporations (Bouchet, 2010). Outsourcing is prominent within sport marketing and particularly the professional football industry where a significant percentage of club revenue is dependent on the role of agencies in attracting partners, sponsors, and in other commercial deals. This captures the principal-agent relationship i.e. relationships in which 'one party (the principal) delegates work to another (the agent), who performs that work' (Eisenhardt, 1989, p. 58). These relationships are commonplace to marketing 'because the essence of marketing is exchange' (Bouchet, 2010, p. 278). Studies that adopt an agency perspective largely emphasise the fundamental conflicts of interest between principals and agents, with an assumption that each party will act in its own self-interest (Gomez-Mejia \& Balkin, 1992) on the premise that 'a principal and agent are not necessarily congruent in terms of (financial) goals' (Lee et al., 2016). Thus, the identified separation 
between the right holder and agent in marketing outsourcing can result in agency problems i.e. conflicts between the principal and agent (Bouchet, 2010). These originate from not only the desires or goals of the principal and agent being in conflict, but also when it is difficult or expensive for the principal to verify what the agent is actually doing. This might manifest in an agent's risky pursuit of objectives that maximise their own gains at the expense of the right holder's objectives (Eisenhardt, 1989), which can damage partnership working and marketing outsourcing effectiveness. This is compounded if an agent has high autonomy, independence, and highly specialised knowledge (Gomez-Mejia \& Balkin, 1992), like sport marketing agents, as monitoring their behaviour and actions can be difficult (c.f. Lee et al., 2016).

However, the role of outsourcing has been neglected in the sport marketing literature with only a small number of notable exceptions, though these have typically focused on the intercollegiate sport setting in the US, with little attention given to other sport settings (c.f. Lee, 2016). Li and Burden (2002, 2004) and Burden and $\mathrm{Li}(2003,2009)$, for example, draw attention to the decision to outsource marketing operations and identify determinants of this decision that include financial-related institutional forces, organisational philosophy, organisational goals, strategic direction, and perception of the general manager; while Lee and Walsh (2011) observe that financial return is the most important driver of outsourcing. Developing insight on the principal-agent relationship in this setting specifically, Walker et al. (2009) observe that the communicative efforts of agents is seen as central to effective marketing outsourcing. Within the same context and also drawing on agency theory, Lee et al. (2016) contend that frequent and continuous interactions between principal and agent are necessary to generate strong ties and trust for successful marketing outsourcing. This application of agency theory to investigate sport 
marketing outsourcing is rare, but one other example is provided by Bouchet (2010) who explores the agency problems among US athletic departments that include losing control of their message and the cost/revenue trade-off.

While these studies have provided invaluable insights, there is 'a lack of understanding of the nature and dynamic of the relationships among employees from the organisations participating in sport marketing outsourcing' (Lee et al., 2016, p. 63). Thus, there is limited understanding of marketing outsourcing from the perspectives of those actors directly involved. In addressing this, we examine how the outsourcing relationship dynamic can be managed successfully (Yang, Wacker, \& Sheu, 2012) by integrating right holder and agency perspectives.

\section{Research setting}

Professional football club marketing and commercial activities generally revolve around the maximisation of four revenue streams: ticketing and hospitality, merchandise, sponsorship and TV rights. The development of these revenue streams is tied closely to the main assets clubs have to offer (e.g. stadium, television coverage, and respective fan base). While overall English Premier League (EPL) clubs have been experiencing significant financial growth with total revenue of Premier League clubs exceeding $£ 3$ billion for 2015 , of which $£ 614$ million was operating profit (rising from $£ 430$ million operating profit in 2014), there is a high level of expenditure, which often results in the clubs experiencing financial losses over the course of a number of seasons (Deloitte, 2015). As a result, wide disparity exists within the league regarding annual turnover.

The sport marketing agency industry in the UK has been gradually developing from a small sub-sector of the wider entertainment industry, to a niche sector of increasing importance, 
with successful international marketing agencies introducing their respective UK branches. Nevertheless, the number of agencies operating within it is still relatively small. Sport marketing agencies focus on the sale and marketing of sport specific 'products', such as sponsorship and advertising agreements, TV right deals, and hospitality sales. Outsourcing agencies include international, national and local agencies of varying sizes, which have at least one department within the company devoted exclusively to sport. A number of these agencies might be operating within the wider leisure or entertainment industry; however, their specialisation for sports differentiates them from generic marketing agencies.

\section{Methods}

Qualitative data was generated from semi-structured interviews with individual marketing managers from 30 EPL football clubs (information on the interviews conducted can be found in Appendix A). The football clubs included in this study participated in the EPL in one or more seasons between 2010 and 2015 (see Appendix B for more information on the sampled clubs). To gather information from the viewpoint of the agency, interviews with 10 agency account managers were conducted. In England, there are less than 50 marketing agencies holding sportrelated projects in their current portfolio ${ }^{1}$. Out of these only 22 identify themselves as sport marketing agencies, from which the ten agencies were sampled. All ten agencies interviewed for this study had been in a contractual relationship with all of the sampled football clubs at some point in time, with some of them maintaining a long-term relationship with these clubs. Within the ten agencies interviewed, a variety of structures and titles were encountered, however, all agencies interviewed had a devoted sport sales team that comprised of approximately 6 people.

\footnotetext{
${ }^{1}$ This number does not include consultancy agencies that offer marketing advice to football clubs as part of a wider package.
} 
Interviews were conducted in person whenever possible to build a good relationship with the interviewee and this also allowed on occasion for visual aids to be used when describing examples. However, some telephone interviews had to be conducted in place of face to face interviews, often due to interviewee scheduling issues or lengthy travel distances. A set of core questions were developed to unpick the marketing outsourcing process from both the right holder and agency perspectives. Mindful of social desirability effects, we also took care to ask similar questions in different ways, probe informants' explanations and justifications in-depth, and triangulate apparent contradictions and inconsistencies. A sample list of interview questions can be found in Appendix C. In total, 40 interviews were conducted between August 2014 and March 2015 and these were then transcribed, producing on average 6-8 pages of single spaced text per interview.

All interview transcripts were sent to the interviewees in order for any inaccuracies or misinterpretations to be pinpointed and for the accuracy of the interviews to be verified. The data was analysed manually through thematic analysis (see Appendix D for key themes and illustrative quotes), which allowed for the codes identified in text to be grouped under overarching themes and sub-themes. Manually coding the data entailed a laborious and lengthy process that included examining the transcriptions meticulously while colour coding the codes and themes that emerged (different shades of each colour were used for each theme) and annotating the transcripts. All themes, sub-themes and codes were then collated on a 'thematic map’, which allowed for the specifics of each theme to be refined. The coding and data analysis process for this study followed the six phases of thematic analysis suggested by Braun and Clarke (2006, p.16). For robustness, the codes and themes identified were verified through intra and inter coding agreement. 


\section{Findings and discussion}

\section{Drivers of the outsourcing decision}

Through detailed discussion with the sampled football clubs on the topic of outsourcing, interviewees highlighted three criteria that drove their decision to outsource: resource scarcity, cost minimisation, and market penetration. These are now discussed.

With regard to resource scarcity, Club AA explained that there are some areas where the club needs to buy-in capacity. A justification given for this was linked to the smallness of the inhouse workforce, whereas the agency had the capacity to pursue leads for B2B products, for example. Clubs such as N, Q and U would only outsource creative work and this would occur when their creative studio would be overburdened. When this additional resource is needed, it is chosen carefully through intelligent tender processes in order to bring in the right vendor at the right price, with a clear preference on long-term relationships.

When our in-house designer has too many things in his hands, or when we need a campaign ASAP, we use a design agency. We've used the same one for many years now, since they know our brand, they have the brand guidelines, they know what we need. Selecting a new agency would be a long process, so we tend to work with the same designer agency, plus we always know how much each project is going to cost. (Club N).

This 'cost focus' was also mentioned by several interviewees as a driving factor. Club Y advised that cost efficiencies are favoured over going through a learning curve or hiring full time staff to cover the same function. In Club S, the decision to outsource means placing a careful eye on the margins tied in with the relationship. While Club J outsource their perimeter advertising 
sales to a third party, highlighting this as a good financial arrangement given the reduced costs involved for the club:

When we (Club J) put the new boards around the pitch, there was so much more advertising we could sell. Now, I could ask my sales team to do it, but that would mean that their workload would be too heavy, their focus would have switched from their current targets and we would have possibly needed additional people. Instead, we just signed a deal with $\mathrm{x}$ and secured a good amount of income, without any additional cost.

It's a good deal, money-wise. We tried selling the shirt sponsorship ourselves and realised early that we just can’t get the price an agency can secure for us. We (Club S) don’t have the sales force or expertise and contacts an agency has. So for us it makes sense to get a 30 million deal through an agency, rather than a 15 million one my sales team can bring.

As Club S discusses, the agency can achieve better results than the club itself and as a result raise the potential revenue of the club without adding costs (e.g. additional members of staff) to the organisation.

Another common reason to outsource relates to market penetration. In practical terms, this means using agencies in order to expand their network of contacts. Club L explained that they use marketing agencies as points of reference to get introduced to companies, since 'you cannot know everyone in the boardroom of a company’. Club X mirrored this view, advising that 'agencies will have contacts that you are never, ever going to bump into'. In both cases, the interviewees were referring mainly to large B2B items, such as high value sponsorship opportunities. For the highest value item in the case of Club W, the naming right to their 
stadium, the club also used an agency primarily 'to open doors'. This driver of using agencies for B2B market penetration is one that Club B laments:

We understand what we can offer better than an agent, we can represent it better than an agent and present it better. The only thing missing is a black book of contacts.

Resource scarcity, cost minimisation, and market penetration seem to be the main drivers of marketing outsourcing in football, and these findings share similarities with both the sport management and marketing literatures, and broader outsourcing studies. For instance, cost minimisation is closely linked to financial-related institutional forces that are identified as important determinants of outsourcing in the US intercollegiate sport setting (Burden \& Li 2003, 2009; Li \& Burden, 2002, 2004), 'put another way, it allows organisations to take employees off their books and place them on the books of the third-party firms' (Bouchet, 2010, p. 281); while this illustrates the cost-driven nature of outsourcing decisions (Lee, 2016) it also contradicts findings reported by Lee and Walsh (2011) who observe that cost minimisation is less important in US intercollegiate sport. Performance is another important determinant identified in the literature (Burden \& Li 2003, 2009; Lee, 2016), consistent with the desire for market penetration observed here. Evidence for the role of resource scarcity in driving outsourcing behaviour has been observed (a) in the outsourcing practices related to health, sport and physical education (e.g. need for expertise) (Williams \& Macdonald, 2015), (b) in college athletic departments that struggle to increase revenue to match expanding budgets (i.e. depletion of resources) (Bouchet, 2010), and (c) in non-sporting contexts, where acquiring greater workforce resources are key drivers (Wei Khong, 2005; Zu \& Kaynak, 2012). While evidence of similarities between the findings presented and existing knowledge is clear, the three drivers uncovered in the football 
setting have not been grouped in the same setting before, which suggests that there may be multiple configurations of drivers to outsource, contingent on the setting examined.

\section{Barriers to outsourcing: A right holder perspective}

While marketing outsourcing appears to be an accepted business practice among the football clubs, the interviewees also spoke of substantial barriers they felt reduced their use of this strategic option. These critical factors included performance uncertainty, fear of being a number in a portfolio, and lack of control, which are now considered.

Club C commented on how working with agencies can cause difficulties from the start of the relationship, as 'brands want to work with the organisation they are investing in; they do not want to be dealing with a middle-man'. Club E also took a negative view of using agencies, citing them to be very costly and very unproductive from past experiences, highlighting performance uncertainty as a major concern. Club I elaborated on this view, suggesting that:

You spend more time trying to manage the agency in what they are communicating, than them actually selling the sponsorship.

When discussing agency portfolios, Club D commented that a debate rages on in their club as to whether to choose a small and hungry agency or one that is larger with international offices and contacts. On average, Club D chooses the small and hungry agency, citing the fear of being just another part of their portfolio. Club Q also expressed the same fear of becoming 'just one part of their portfolio’: 
Agencies will say to clients 'We have Club Q, the National Basketball Association, the Rugby Football Union, etc.' This means Club Q are just part of a mix that they throw at clients hoping some of it sticks.

For Club U, the view taken is that agencies can be a useful short-term resource to help meet a specific requirement, as long as a tight control on the relationship is maintained. Club Y underlined this point by adding that 'rigorous' contracts must be enforced. This need for control within the relationship is further elaborated on by Club AA who states that the agency can do the groundwork, gauging interest in the offering and setting up meetings but the club must take the lead:

The service an agency offers includes finding a prospect, but that prospect needs to know that I'm in control, not the agency. They need to know that the deal will be signed with me, not the agency. So I step in to make it clear.

The perception of the 'manager' has been previously identified as a critical feature in sport marketing outsourcing (Burden \& Li 2003, 2009; Li \& Burden, 2002, 2004) and we extend the implications of this here. When clubs perceive a danger that they will simply become a number in a portfolio, the potential value creation of entering such a relationship is devalued and thus acts as a constraint to entering into an outsourcing partnership with an agent. This is supported by empirical evidence from outside of the sporting context where the principal prefers agents that can generate significant value for the firm (Ni \& Srinivasan, 2015). Similarly, then, performance uncertainty reduces the likelihood of value creation and deters clubs from outsourcing. The perceived loss of control has also been observed as a disadvantage of 
outsourcing in US athletic departments (Bouchet, 2010), with Walker et al. (2009) similarly highlighting the potential loss of control for the client. The findings reported here in the football context are consistent with previous studies from different settings, thus offering further support for existing understanding of barriers to outsourcing from the principals' perspective; though, we note again that the configuration of barriers appears to be contingent on the setting examined.

\section{Motivations of sport marketing agents}

On the other side of the interface, detailed discussion with sampled agencies on the topic of outsourcing highlighted six criteria that motivated their partnership working: good brand potential, strong financial position, professionalism of senior management, compliments existing relationships, appropriate contract length, and exploits newness. These are now discussed.

For an agency entering into a contractual relationship with a right holder, all ten interviewees highlighted that the most important factor is 'potential'. Agency 1 underlined potential as the club being able to leverage its local and regional position to build its B2B partners. Agency 2 viewed potential more in terms of the brand (i.e. the name of the club and its stature). Agency 6 took this further by saying the club must be a traditional brand, one that has been known in the market for a long time. The argument is that a well known club that is seen as having traditional values is more likely to be successful in drawing upon the economic potential of their local region.

Other elements agencies look for lie in the overall financial position of the club. As Agency 10 pointed out, this should not be ‘too extreme'. Agency 3 describes this element as a club needing to provide a degree of financial reliability. Intertwined with the financial situation of the club is the professionalism of senior management. The interviewees stressed the 
importance of a professional management structure within clubs for effective marketing outsourcing, however all interviewees commented on the lack of professionalism found among right holders, as Agency 7 illustrates:

When an exclusive partnership agreement was being signed and the club were asked to produce their sponsorship and B2B contracts, they produced a folder with loose pieces of paper and napkins on which agreements were signed.

Additional challenges can include the type of relationship the agency has with a local rival of a club. For example, it would be a conflict of interest if an agency were to be closely involved with two major clubs in one city; as the agency could find themselves trying to sell a shirt sponsorship deal for both clubs, at the same time. In order to generate sufficient sales volume, all agencies identified the importance of a long-term partnership in order to create, build and maximise an outsourcing partnership within its overall network; citing a duration of 4-5 years.

In discussing the role of marketing tools to reach the required sales volume, agencies stressed the need for a club to have something 'new' to work with (Agency 7). This can be in the form of a new manager, a new president or a new owner. However, this 'new' element usually takes the form of the club facilities and in particular the stadium. As Agency 5 explained, the stadium is the 'ID card of a football club'. The argument for improving the sales volume through this opportunity is two-fold. A new stadium shows the local area / region that something new is happening and that everyone (including local companies) should be a part of this (Agency 6). Additionally, a new or improved stadium offers the potential to set up a 'hospitality world' (Agency 9), which allows for a 'premium pricing scheme’ (Agency 4). 
Typically, the sport management and marketing literatures study outsourcing from the perspective of the principal (i.e. the right holder, athletics departments, etc.) and as a result this has informed a growing body of evidence on the motivations of outsourcing, categorised as either cost and/or performance driven (Lee, 2016). However, by neglecting the agents' perspective, the motivations for outsourcing as currently understood are biased to a single perspective (the principals') with unfounded assumptions remaining that agents are only concerned about revenue (Bouchet, 2010). By offering a more balanced view from both sides of the outsourcing interface, it is clear that potential for revenue generation does indeed feature in agents' search for desired clients, for instance, the following observed motivations speak to this objective: 'good brand potential', 'strong financial position', and 'exploits newness'. However, the agents' motivations are more salient than being simply revenue-oriented and address the importance of ensuring a quality partnership is achieved, which then in turn may result in enhanced effectiveness. For example, 'professionalism of senior management', 'compliments existing relationships', and 'appropriate contract length', reflect a wider value proposition beyond monetary reward. This is supported in the context of marketing firms matching with manufacturers, where partnerships that can generate significant value are central to the outsourcing relationship (Ni \& Srinivasan, 2015). Though, 'previous outsourcing literature does not consistently support better outsourcing outcomes based on longer contract duration' (Lee et al., 2016, p. 73), agency theory contends that in long-term relationships principals learn more about agents thus minimising agency problems (Zu \& Kaynak, 2012), and this certainly appears to be a fundamental motivation for agents observed here.

\section{Constraints on marketing outsourcing: An agency perspective}


In discussing their motivations, the agencies interviewed also raised key constraints originating from the right holders' that they believed damaged the marketing outsourcing interface. Five such constraints were highlighted and include: unrealistic expectations, agency staff made unwelcome, agency profit creating jealousy, and negative agency experience. These are now presented and discussed.

Agency 1 points out that at the beginning of the agreement 'club expectations of the agency and the future partnership are extremely high'. This is a result of all clubs believing that they are successful thereby engaging in such a partnership with an agency should only bring even greater success at a faster rate (Agency 1). As Agency 3 states:

Bringing each club's expectations down to Earth is the trickiest part of our relationship. Every single club we've worked with thought they are worth more than they are in the marketplace, so we had to be the ones managing these expectations.

The way in which agencies manage this is by working very closely with their right holder partners. In practical terms, working closely with the right holder means the agency places their own small team in or next to the club head office and in the opinion of Agency 7, 'this is the secret of our success'. Agency 6 consolidates this point by saying that this approach allows the parties to start working early together on all products, meaning they can go to the market in a structured way, bringing the product to market through a professional sales system. It is acknowledged by all agency interviewees that for a right holder, accepting this approach of working closely with an agency on-site is a huge decision. It is a big change for a club from their previous structure and it is possible for people within the club to be 'scared because of these changes’ (Agency 6). 
It is sometimes difficult to accept new people in your own office. At first there is no team spirit and not even a shared understanding of our role within the club. It takes a while to be accepted within each club and even more to build any actual trust. (Agency 6).

However, Agency 5 explains that agency staff are 'generally not welcome'. This appears to be rooted in agencies being perceived as money generators for the club (Agency 3), or as purely a sales force (Agency 1). According to Agency 5, the more money a right holder gains through its partnership with an agency the less satisfied the right holder becomes. Agency 4 acknowledges that calculating the revenue share/costs is a point of conflict that can even lead to the termination of a profitable agreement. That is because, in the view of Agency 2, the club will always say 'we want more money'.

Clubs tend to think that we can help them get some revenue, but occasionally forget that we need to get something out of the deal too. We often see our partner club unhappy when our percentage of each sale is calculated, even though the terms of our agreement were clear from the beginning. (Agency 5).

There is an overall belief from the interviewees that the general manner in which the right holder acts within the relationship is determined by previous experiences the right holder has had with past agencies. For example, if the past agency did not meet expectations or add value, the approach of the right holder to future agency collaboration is likely to be very negative (Agency 9). As Agency 1 highlights: 
If a club has had a bad experience with another agency, we will always be judged based on what this previous experience was, which is not fair.

Lee (2016) suggests that outsourcing risks identified in sport management and marketing studies are consistent across this growing body of research, and also with general outsourcing studies. However, because the majority of studies do not seek to reflect both sides of the principal-agent relationship equally, existing understanding is skewed toward the risks or constraints for the principal (e.g. Bouchet, 2010; Williams\& Macdonald, 2015). This study deviates away from prioritising one party over the other and in doing so offers new insights into the constraints on marketing outsourcing, as experienced by both the right holders and agencies involved. Here, it is evident that the right holder can jeopardise effective partnership working by setting unrealistic expectations, making agency staff feel unwelcome, and allowing agency revenue generation to create jealousy. Curiously, these actions on the part of the right holder are counter intuitive as they serve to destroy their own returns that would otherwise be generated from an effective partnership. That is not to say, however, that agencies themselves carry no blame, since negative past experiences of working with agencies is highlighted by agencies as a constraint on their future partnerships with right holders. This insight from a neglected perspective portrays a more complex picture to sport marketing outsourcing than has typically been studied.

\section{Marketing outsourcing: Making it work}

Particular characteristics emerged from the data that appeared to underpin successful marketing outsourcing relationships, nurturing the drivers and motivations of the parties involved whilst 
reducing perceived barriers and constraints, and these included: long-term orientation, commitment, ongoing operational and strategic oversight, inclusion, and trust.

From a right holder perspective barriers to outsourcing revolve around loss of control, fear of being part of a portfolio, and performance uncertainty, leading to a rather piecemeal approach to marketing outsourcing. In contrast, a number of clubs adopted a more strategic approach viewing the outsourcing relationship as a feature of their competitiveness in the market. This is illustrated by club $\mathrm{H}$ who make a 'two-pronged attack' on the market by coupling their own sponsorship team with two lead agencies to build their sponsorship portfolio. Club L, for instance, works on a long-term retainer basis to maximise the potential of the relationship, as in their words: 'agencies are learning organisations and a cumulative effect can be felt through this method as it allows for the agency to get under the skin [of the right holder] at many different levels’. As Club L elaborates:

We were never looking for a quick fix or a quick cash deal. We wanted a long-term partnership with an organisation that understands who we are and respects our views. We think that this can help the agency appreciate the club, which in the end benefits us.

Club L also offers insight from their experience of working on both the agency side and the right holder side; he explains that a right holder must commit to an agent if they wish to receive the best service available from that agency. So there are clear roles here for commitment and trust if the relationship is to work.

When we choose an agency, we choose a partner; someone who will work for us and will look out for us. We can't expect them to be committed and focused, if we don't show 
commitment and trust ourselves. We always make sure that any agency we're working with becomes part of our team, especially if we're building a long-term relationship with them. (Club Z).

This is echoed from the agency perspective as all interviewees commented that the right holder-agency relationship is something that must be well managed throughout the partnership agreement. It is an ongoing management duty through the on-site team at an operational level, as well as at a strategic level by senior decision makers from both parties. On an operational level, the agency requires sympathetic employees who possess strong social skills to carefully manage the integration and implementation of the on-site team (Agency 1). The approach to take during this introductory phase is an inclusive one, where discussions should be held together between agency and club employees concerning all tasks. The introduction of new ideas and processes must be done at a pace which is comfortable for the right holder, with the goal of working together to provide a solution that is mutually beneficial. When the relationship is continually monitored so that it functions well, the outsourcing relationship appears to be stronger as 'every employee (agency or club) celebrates a winning goal together’ (Agency 4).

At the end of the process, we end up being a big team. But in order to get there, we need some help from the club. We need to be given clear directions on all aspects, both the operational everyday tasks, and the overall strategic targets. We are trying to become part of the team and helping us can only speed this process up, which can in turn only lead to better and bigger rewards. (Agency 1). 
Taken collectively, ‘long-term orientation', 'commitment', 'trust’, 'ongoing operational and strategic oversight', and 'inclusion' appear to be essential conditions for an effective outsourcing interface. From the nonsporting context, ineffective outsourcing relationships are typically characterised by poor management of relationships (e.g. lack of strategic and operational oversight), and/or a distrustful atmosphere (e.g. lack of trust) that triggers agency problems, with incentivisation, information sharing and goal congruence as proposed solutions (Fayezi, O'Loughlin, \& Zutshi, 2012). In sport, Walker et al. (2009) observe that internal employees value the communicative efforts of their outside agencies (observed here as inclusion) and this is supported by Lee et al. (2016) who contend that frequent and continuous interactions (e.g. inclusion) between principal and agent are necessary to generate strong ties and in turn successful marketing outsourcing. Lee et al. (2016) also highlight the need for operational and strategic oversight and while they contend that this is typical given the small number of staff involved and their close proximity across the interface, clearly in the football context this does not occur frequently enough. A long-term orientation and commitment to the relationship have not been explicitly discussed before as necessary features for effective sports marketing outsourcing, but tap into the logic that when principals have more opportunity to learn about agents over time, and we would argue vice versa, agency problems are minimised ( $\mathrm{Zu} \&$ Kaynak, 2012) thus enhancing the effectiveness of outsourcing across the interface.

The findings are integrated in figure 1 to illustrate the dynamic nature of the marketing outsourcing relationship, from the experiences of the key players involved (see Appendix D for list of themes and illustrative quotes). Lee (2016, p. 18) contends that 'outsourcing as a business strategy can be an impactful business decision as it can provide a strategic opportunity for the sport organisation to obtain competitive advantages', and while we agree, we would argue that 
the success of marketing outsourcing is dependent upon the balance of conditions across the right holder/agency interface. Specifically, while pushing factors may contribute to effective marketing outsourcing, resisting factors seek to undermine the right holder-agency relationship. However, in nurturing key necessary features both parties can limit resisting factors and emphasise push factors for shared value creation.

Figure 1. Making it work: Marketing outsourcing at the right holder/agency interface

\begin{tabular}{|l|r|}
\hline Pushing & Resisting \\
Right holder & Right holder \\
Resource scarcity; & Performance uncertainty; \\
Cost minimisation; & Lack of control. \\
Market penetration. & Agency \\
Agency & Fear of being a number in a portfolio \\
Good brand potential; & Unrealistic expectations; \\
Strong financial position; & Agency staff made unwelcome; \\
Professionalism of senior management; & Agency profit creating jealousy; \\
Compliments existing relationships; & Negative agency experience. \\
Appropriate contract length; & \\
Exploits 'newness'. & \\
\hline
\end{tabular}

\section{Necessary Features}

Long-term orientation; Commitment; Trust; Ongoing operational and strategic oversight; Inclusion.

\section{Limitations and future research}

We acknowledge several limitations of this study. First, it is based on a single research setting and therefore the transferability of findings to other settings may be limited; nevertheless this study can aid in naturalistic generalisation i.e. we expect similar patterns to be observed in 
similar cases. Second, data were generated from a single respondent in each club and in each agency sampled and while the number of staff involved in marketing outsourcing is very small (Lee et al., 2016), seeking the opinions of wider organisational stakeholders would have generated greater validity in the experiences reported. Third, the purpose of this study was to examine how marketing outsourcing can be managed successfully from the principal and agent perspectives; hence we did not seek to assess the success of outsourcing partnerships. A longitudinal investigation of this interface over the duration of a typical contract would provide the opportunity to determine the importance of pushing factors, resisting factors, and necessary features for value creation for both parties, while allowing for both effective and ineffective outsourcing outcomes to be examined. This is a worthy avenue for future research.

\section{Conclusion}

By capturing both sides of the right holder/agency interface, this study has highlighted a neglected perspective (i.e. of the agency) in the sport management and marketing literatures to more accurately examine the principal-agency relationship in marketing outsourcing. Drawing on agency theory adds a novel extension of a general business and management theory to an overlooked research setting in the business and management field: professional football clubs, and in doing so further develops the overall body of literature as called for by Lee et al. (2016). The environmental peculiarities of this setting offer a different interpretation of the principalagent relationship than is typically studied. Rather than examine the role of formal governance mechanisms, outcome-based and behaviour-based approaches, or formal and informal networks to more effectively manage the right holder/agency relationship (e.g. Lee et al., 2016; Yang et al., 2012; Zu \& Kaynok, 2012), this study captures the salient pushing and resisting forces at 
play as experienced across the interface. In doing so, we contribute to the outsourcing literature more broadly by moving away from a sole focus on the principal, which has informed supplier selection criteria for instance (e.g. Kotula et al., 2015), to provide a more accurate understanding of the outsourcing relationship dynamic as experienced by the actors directly involved. To the sport management and marketing literatures specifically, this approach adds greater nuance to

the drivers/motivations and barriers/constraints in marketing outsourcing that are typically cited, providing a new framework to guide successful marketing outsourcing across the right holder/agency interface.

\section{References}

Bouchet, A. (2010). Linking outsourcing of sponsorships to athletic department strategy: An agency perspective. Journal of Sponsorship, 3(3), 277-283.

Braun, V., \& Clarke, V. (2006). Using thematic analysis in psychology. Qualitative research in psychology, 3(2), 77-101.

Brooksbank, R., Garland, R., \& Werder, W. (2012) Strategic marketing practices as drivers of successful business performance in British, Australian and New Zealand golf clubs. European Sport Management Quarterly, 12(5), 457-475.

Burden, W., \& Li, M. (2003). Differentiation of NCAA Division 1 athletics departments in outsourcing of sport marketing operations: Discriminant analysis of financial-related institutional variables. International Sports Journal, 7(2), 74-81.

Burden, W., \& Li, M. (2009). Minor league baseball: Exploring the growing interest in outsourced sport marketing. Sport Marketing Quarterly, 18(3), 139-149. 
Campos, C. (2002). Interview with José Ángel Sánchez Real Madrid club de fútbol's general marketing director. European Sport Management Quarterly, 2(3), 234-242.

Couvelaere, V., \& Richelieu, A. (2005) Brand strategy in professional sports: The case of French soccer teams. European Sport Management Quarterly, 5(1), 23-46.

Deloitte. (2015). Football Money League. Manchester: Deloitte.

Eisenhardt, K, M. (1989). Agency theory: An assessment and review. Academy of Management Review, 14(1), 57-74.

Fayezi, S., O'Loughlin, A., \& Zutshi, A. (2012). Agency theory and supply chain management: a structured literature review. Supply Chain Management: An International Journal, 17(5), 556-570.

Gomez-Mejia, L.R., \& Balkin, D.B. 1992. Determinants of faculty pay: An agency theory perspective. Academy of Management Journal, 35(5), 921-955.

Kotula, M., Ho, W., Dey, P.K., \& Lee, C.K.M. (2015). Strategic sourcing supplier selection misalignment with critical success factors: Findings from multiple case studies in Germany and the United Kingdom. International Journal of Production Economics, 166, 238-247.

Lee, S. (2016). Economic view and strategic management view toward understanding outsourcing in amateur sport. Journal of Amateur Sport, 2(1), 12-38.

Lee, S., Oh, N., \& Juravich, M. (2016). Examination of formal and informal relationships between service provider and client for ticket sales outsourcing in the United States. Journal of Relationship Marketing, 15(1-2), 62-80.

Lee, S., \& Walsh, P. (2011). SWOT and AHP hybrid model for sport marketing outsourcing using a case of intercollegiate sport. Sport Management Review, 14(4), 361-369. 
Li, M., \& Burden, W. (2002). Outsourcing sport marketing operations by NCAA Division I athletic programs: An exploratory study. Sport Marketing Quarterly, 11(4), 226-232.

Li, M., \& Burden, W. (2004). Institutional control, perceived product attractiveness and other related variables in affecting athletic administrators' outsourcing decisions. International Journal of Sport Management, 5(4), 295-305.

McGovern, G., \& Quelch, J. (2005). Outsourcing marketing. Harvard Business Review, 83(3), 22-26.

Ni, J., \& Srinivasan, K. (2015). Matching in the sourcing market: A structural analysis of the upstream channel. Marketing Science, 34(5), 722-738.

Quinn, J. B. (1999). Strategic outsourcing: leveraging knowledge capabilities. MIT Sloan Management Review, 40(4), 9.

Walker, M., Sartore, M., \& Taylor, R. (2009). Outsourced marketing: It's the communication that matters. Management Decision, 47(6), 895-918.

Walsh, P., \& Lee, S. (2012). Development of a brand extension decision-making model for professional sport teams. Sport Marketing Quarterly, 21(4), 232.

Wei Khong, K. (2005). The perceived impact of successful outsourcing on customer service management. Supply Chain Management: An International Journal, 10(5), 402-411.

Williams, B.J., \& Macdonald, D. (2015). Explaining outsourcing in health, sport and physical education. Sport, Education and Society, 20(1), 57-72.

Yang, C., Wacker, J.G., \& Sheu, C. (2012). What makes outsourcing effective? A transactioncost economics analysis. International Journal of Production Research, 50(16), 44624476. 
Zu, X., \& Kaynak, H. (2012). An agency theory perspective on supply chain quality management. International Journal of Operations \& Production Management, 32(4), 423-446. 
Appendix A. Data audit

\begin{tabular}{|c|c|c|c|c|c|c|}
\hline Organisation & $\begin{array}{l}\text { Level within the } \\
\text { organisation }\end{array}$ & $\begin{array}{l}\text { Years of } \\
\text { employment } \\
\text { (organisation) }\end{array}$ & $\begin{array}{l}\text { Experience } \\
\text { outside the } \\
\text { industry }\end{array}$ & $\begin{array}{l}\text { Years of } \\
\text { employment } \\
\text { (total) }\end{array}$ & $\begin{array}{l}\text { Length of } \\
\text { interview }\end{array}$ & $\begin{array}{l}\text { In-person / } \\
\text { telephone } \\
\text { interview }\end{array}$ \\
\hline Club A & Head of department & 4 & No & 13 & $65 \min$ & In-person \\
\hline Club B & Head of department & 6 & Yes & 14 & $67 \min$ & In-person \\
\hline Club C & Head of department & 3 & No & 15 & 72min & In-person \\
\hline Club D & Head of department & 7 & Yes & 12 & $64 \mathrm{~min}$ & Telephone \\
\hline Club E & $\begin{array}{l}\text { Middle } \\
\text { management }\end{array}$ & 6 & No & 6 & $78 \mathrm{~min}$ & In-person \\
\hline Club F & $\begin{array}{l}\text { Middle } \\
\text { management }\end{array}$ & 4 & Yes & 8 & $80 \mathrm{~min}$ & In-person \\
\hline Club G & Head of department & 5 & Yes & 29 & $64 \min$ & In-person \\
\hline Club H & Head of department & 6 & No & 11 & $60 \mathrm{~min}$ & Telephone \\
\hline Club I & $\begin{array}{l}\text { Middle } \\
\text { management }\end{array}$ & 15 & No & 20 & $67 \mathrm{~min}$ & Telephone \\
\hline Club J & $\begin{array}{l}\text { Middle } \\
\text { management }\end{array}$ & 8 & Yes & 10 & $50 \mathrm{~min}$ & In-person \\
\hline Club K & $\begin{array}{l}\text { Middle } \\
\text { management }\end{array}$ & 9 & No & 25 & $48 \mathrm{~min}$ & In-person \\
\hline Club L & Head of department & 10 & No & 28 & 72min & In-person \\
\hline Club M & Head of department & 1 & Yes & 11 & $64 \mathrm{~min}$ & In-person \\
\hline Club N & Head of department & 4 & No & 14 & $60 \mathrm{~min}$ & In-person \\
\hline Club O & Head of department & 6 & Yes & 25 & $62 \mathrm{~min}$ & In-person \\
\hline Club P & Head of department & 14 & No & 16 & $65 \mathrm{~min}$ & In-person \\
\hline Club Q & Head of department & 12 & No & 18 & $63 \mathrm{~min}$ & In-person \\
\hline Club R & Head of department & 5 & Yes & 23 & $66 \mathrm{~min}$ & In-person \\
\hline Club S & $\begin{array}{l}\text { Middle } \\
\text { management }\end{array}$ & 3 & No & 7 & $58 \mathrm{~min}$ & In-person \\
\hline Club T & Head of department & 2 & Yes & 15 & $74 \min$ & Telephone \\
\hline Club U & Head of department & 4 & No & 8 & $66 \mathrm{~min}$ & Telephone \\
\hline Club V & Head of department & 5 & No & 19 & $62 \mathrm{~min}$ & In-person \\
\hline Club W & Head of department & 6 & No & 8 & $61 \mathrm{~min}$ & In-person \\
\hline Club X & Head of department & 1 & No & 14 & 59min & In-person \\
\hline Club Y & Head of department & 8 & Yes & 26 & $70 \mathrm{~min}$ & In-person \\
\hline Club Z & $\begin{array}{l}\text { Middle } \\
\text { management }\end{array}$ & 3 & No & 6 & $72 \mathrm{~min}$ & In-person \\
\hline Club AA & Head of department & 5 & Yes & 12 & $62 \mathrm{~min}$ & Telephone \\
\hline Club AB & $\begin{array}{l}\text { Middle } \\
\text { management }\end{array}$ & 4 & Yes & 14 & $58 \mathrm{~min}$ & In-person \\
\hline Club AC & $\begin{array}{l}\text { Middle } \\
\text { management }\end{array}$ & 2 & Yes & 6 & $60 \mathrm{~min}$ & In-person \\
\hline Club AD & Head of department & 30 & No & 30 & $61 \mathrm{~min}$ & In-person \\
\hline Agency 1 & Head of department & 6 & Yes & 24 & $84 \mathrm{~min}$ & In-person \\
\hline Agency 2 & Head of department & 4 & No & 19 & $78 \mathrm{~min}$ & In-person \\
\hline Agency 3 & Head of department & 5 & Yes & 20 & $65 \mathrm{~min}$ & In-person \\
\hline Agency 4 & Head of department & 6 & Yes & 17 & $70 \mathrm{~min}$ & In-person \\
\hline Agency 5 & Head of department & 10 & No & 18 & 71min & In-person \\
\hline Agency 6 & Head of department & 8 & No & 10 & $75 \mathrm{~min}$ & In-person \\
\hline Agency 7 & Head of department & 3 & No & 14 & 74min & In-person \\
\hline Agency 8 & Head of department & 4 & No & 12 & $73 \mathrm{~min}$ & In-person \\
\hline Agency 9 & $\begin{array}{l}\text { Middle } \\
\text { management }\end{array}$ & 4 & No & 8 & $78 \mathrm{~min}$ & In-person \\
\hline Agency 10 & Head of department & 2 & Yes & 25 & $81 \mathrm{~min}$ & In-person \\
\hline
\end{tabular}


Appendix B. Profile of sampled clubs

\begin{tabular}{|c|c|c|c|c|}
\hline Club & Founded in & Location & $\begin{array}{l}\text { Years in the } \\
\text { Premier League } \\
\text { since it was } \\
\text { founded }^{2}\end{array}$ & $\begin{array}{l}\text { Average } \\
\text { turnover in a } \\
\text { PL season }{ }^{3} \\
\text { (in } £ \text { million) }\end{array}$ \\
\hline Arsenal & 1886 & Holloway, London & 23 & 272 \\
\hline Aston Villa & 1874 & Witton, Birmingham & 23 & 93.25 \\
\hline Birmingham City & 1875 & Birmingham & 7 & 56 \\
\hline Blackburn Rovers & 1875 & Blackburn & 18 & 58 \\
\hline Blackpool & 1887 & Blackpool & 1 & 52 \\
\hline Bolton Wanderers & 1874 & Bolton & 13 & 68 \\
\hline Burnley & 1884 & Burnley & 2 & \\
\hline Cardiff City & 1899 & Cardiff & 1 & 83 \\
\hline Chelsea & 1905 & Fulham, London & 23 & 266.5 \\
\hline Crystal Palace & 1905 & South Norwood, London & 6 & 90 \\
\hline Everton & 1878 & Liverpool & 23 & 92.5 \\
\hline Fulham & 1879 & Fulham, London & 13 & 80 \\
\hline Hull City & 1904 & Hull & 4 & 84 \\
\hline Leicester City & 1884 & Leicester & 9 & 5 \\
\hline Liverpool & 1892 & Liverpool & 23 & 203.75 \\
\hline Manchester City & 1880 & Manchester & 18 & 250.5 \\
\hline Manchester United & 1878 & Manchester & 23 & 361.75 \\
\hline Newcastle United & 1892 & Newcastle upon Tyne & 21 & 102 \\
\hline Norwich & 1902 & Norwich & 7 & 81 \\
\hline Queens Park & 1882 & White City, London & 7 & 62.5 \\
\hline \multicolumn{5}{|l|}{ Rangers } \\
\hline Reading & 1871 & Reading & 3 & 51.5 \\
\hline Southampton & 1885 & Southampton & 16 & 89 \\
\hline Stoke City & 1863 & Stoke-on-Trent & 7 & 75.75 \\
\hline Sunderland & 1879 & Sunderland & 14 & 84.25 \\
\hline Swansea & 1912 & Swansea & 4 & 76.67 \\
\hline Tottenham Hotspur & 1882 & Tottenham, London & 23 & 158.75 \\
\hline $\begin{array}{l}\text { West Bromwich } \\
\text { Albion }\end{array}$ & 1878 & West Bromwich & 9 & 70.75 \\
\hline West Ham United & 1895 & Newham, London & 19 & 83.5 \\
\hline Wigan Athletic & 1932 & Wigan & 8 & 53.33 \\
\hline $\begin{array}{l}\text { Wolverhampton } \\
\text { Wanders }\end{array}$ & 1877 & Wolverhampton & 4 & 64 \\
\hline
\end{tabular}

\footnotetext{
${ }^{2}$ The total number of seasons was calculated from 1992 when the Premier League was founded, until and inclusive of the 2014/15 season (Premier League, 2015)

${ }^{3}$ Average turnover while playing in the Premier League in the seasons 2010/11, 2011/12, 2012/13, 2013/14, 2014/15 calculated using the date from the Deloitte reports (2012; 2013; 2014; 2015).

${ }^{4}$ Data not available yet since the club played in the Premier League only in 2014/15 season

${ }^{5}$ Data not available yet since the club played in the Premier League only in 2014/15 season
} 


\section{Appendix C. Sample list of interview questions}

Club interviewees

1. Can you describe your role in the club?

2. Can you tell me a few things about your background?

3. Do you work with any marketing agencies?

4. What type of a relationship do you have with them?

5. Would you say that your department has embraced this relationship?

6. Do you feel that the club has embraced this relationship?

7. What would make you select one agency for all tasks?

8. Why did you start working with agencies?

9. Why did you select these particular agencies?

10. Is there a particular selection process?

11. What could make you keep a long-term relationship with a particular agency?

12. What aspects could help build a good relationship with an agency?

13. What aspects would put you off working with an agency?

14. Do you think clubs should collaborate with marketing agencies? Is there a future in this collaboration?

15. Are there things that should improve in order for this to happen?

16. Are there things the clubs should improve in order for this to happen?

Agency interviewees

1. Can you describe your role in the agency?

2. Can you tell me a few things about your background?

3. Are you currently contracted with any football clubs? Which ones?

4. What type of a relationship do you have with them?

5. How closely do you work with them?

6. Would you say that your team has embraced this relationship?

7. Do you feel that the club has embraced this relationship?

8. Why do you think clubs selected you to work with?

9. What would make a club collaborate only with you?

10. What would make you agree to work with a particular club?

11. Why did you agree to work with these particular football clubs?

12. What has been the longest relationship you've ever had with a club?

13. What aspects could help build a good relationship with a club?

14. What aspects would put you off working with a club?

15. Have you stopped working with clubs in the past because of any of these reasons?

16. Do you think clubs should collaborate with marketing agencies? Is there a future in this collaboration? 
Appendix D. key themes and illustrative quotes ${ }^{6}$

\begin{tabular}{|c|c|}
\hline Key Themes & Illustrative Quotes across the rights holder/agency interface \\
\hline \multicolumn{2}{|c|}{ Drivers (right holder) } \\
\hline Resource scarcity; & $\begin{array}{l}\text { 'Sometimes, my sales team can't do it all. Opportunities may arise, but we just } \\
\text { don't have the sales force needed to address it. That's when an agency might } \\
\text { come in and help.' (Club S) }\end{array}$ \\
\hline Cost minimisation; & $\begin{array}{l}\text { 'With an agency, things get easy. We don't have to spend money to plan and } \\
\text { design a new sales pitch, or even take time of our schedule to look into the } \\
\text { details of potential clients. Getting an agency to do that saves us time and } \\
\text { money.' (Club AA) }\end{array}$ \\
\hline Market penetration; & $\begin{array}{l}\text { 'We can try hard to get new contacts and attract new partners, but it is just } \\
\text { not that easy. An agency is hired to do exactly that. They have the contacts, } \\
\text { the links, we want in so many industries and they can help us get the deals we } \\
\text { need.' (Club L) }\end{array}$ \\
\hline \multicolumn{2}{|c|}{ Barriers (right holder) } \\
\hline $\begin{array}{l}\text { Performance } \\
\text { uncertainty; }\end{array}$ & $\begin{array}{l}\text { 'We worked with agencies before and it didn't offer something substantial to } \\
\text { the club. I want to keep an open mind about it, but I don't believe that their } \\
\text { performance is always up to the standards they promise, so it might not be } \\
\text { worth the trouble all the time.' (Club E) }\end{array}$ \\
\hline $\begin{array}{l}\text { Fear of being a } \\
\text { number in a } \\
\text { portfolio; }\end{array}$ & $\begin{array}{l}\text { 'We have a strong identity and a wide reach in the region and even the } \\
\text { country, so we can't be just considered a number on someone's book. We } \\
\text { need to ensure that an agency will give us the attention we deserve.' (Club P) }\end{array}$ \\
\hline Lack of control; & $\begin{array}{l}\text { 'An agreement needs to be made between company } X \text { and the club, not } \\
\text { between company } X \text { and an agency. We need to control the situation at all } \\
\text { time, so that all parties involved can appreciate that.' (Club M) }\end{array}$ \\
\hline \multicolumn{2}{|c|}{ Motivations (agency) } \\
\hline Brand potential; & $\begin{array}{l}\text { 'We will always favour the clubs that have been around for a while. If the club } \\
\text { has been known, then its brand is clearer to the audience, which will make our } \\
\text { job easier.' (Agency 8) }\end{array}$ \\
\hline Financial position; & $\begin{array}{l}\text { 'Before we agree to work with a club, we always ensure that it is 'financially } \\
\text { healthy'. We can't start working on finding it a sponsor when we're afraid } \\
\text { that the club might go into administration any minute.' (Agency 4) }\end{array}$ \\
\hline Senior management; & $\begin{array}{l}\text { 'Even though things are getting better, you would be surprised by how } \\
\text { unprofessional some clubs are. We try to be careful with our partnerships, } \\
\text { since we can't work with people that don't know how to design and follow and } \\
\text { a strategy, or draft and adhere to a plan.' (Agency 6) }\end{array}$ \\
\hline $\begin{array}{l}\text { Existing } \\
\text { relationships; }\end{array}$ & $\begin{array}{l}\text { 'We have to respect the rivalries on the pitch, so we can't work with clubs } \\
\text { from the same city or area for example. If we've signed with one, any rivals } \\
\text { are out of reach for us.' (Agency 2) }\end{array}$ \\
\hline Contract length; & $\begin{array}{l}\text { 'There needs to be a long-term commitment from both sides. Time and effort } \\
\text { will be invested in understanding the club and building a relationship with its }\end{array}$ \\
\hline
\end{tabular}


employees, which would be too costly for us to do for a short-term agreement. We tend to favour 5 years agreements with the clubs.' (Agency 5)

Newness;

'We can always find something good to work on in each club, their brand, their history, something. But if there is a new aspect to it, a new owner, a new stadium, a new star player, then our job is easier. I can sell something 'new' in a higher price.' (Agency 7)

\section{Constraints (agency)}

Unrealistic

'Clubs need to realise that sometimes their expectations are not realistic. The expectations; way their fans see them might not correspond to how a potential sponsor might see them, or how much they are in fact willing to invest for a shirt sponsorship.' (Agency 10)

Agency staff made unwelcome; 'We do not want to compete with the sales guys or get their job. We just want to work together to achieve the best result possible. Animosity towards us does not help the situation at all.' (Agency 8)

Agency profit 'It is rather peculiar to see their reactions when we are being paid for the job creating jealousy; we did. We bring in money and are getting paid for what we do. We shouldn't be seen or treated as beggars.' (Agency 4)

Negative agency 'I understand that there have been problems with other agencies in the past, experience; but we have to be judged on our own work, not the work of other colleagues. If a club has had a bad experience with another agency, we will always be judged based on what this previous experience was, which is not fair.'

(Agency 1)

\begin{tabular}{ll}
\hline $\begin{array}{l}\text { Necessary Features (rights holder and agency) } \\
\text { Long-term } \\
\text { orientation; }\end{array}$ & 'We need long-term partnerships, not quick fix deals. We need to know that \\
& we're building something together in order to motivate our staff to accept the \\
agency as part of their team and give their best. We don't want to feel that \\
we're just a number in your agenda.' (Club Q) \\
'We are always committed to our deals, but need to see this commitment from \\
the other side too. If we're treated like a partner, we will treat you like a \\
partner too.' (Agency 9) \\
'If you can't trust each other, then you are doomed to fail. We are working \\
together for the same targets, not racing against each other for the finishing \\
line. We always place emphasis on building trust early in each partnership.' \\
(Agency 2) \\
'You can't expect my people to know what to do from day one. The club needs \\
to overlook the whole process and to make sure that they're integrated and \\
and operational \\
fully informed. The aim and targets need to be clear and there needs to be \\
supervision that overlooks this.' (Agency 6) \\
'We all need to work as a team, all together. We need to be integrated in a big \\
team that can function better than two separate ones.' (Club G)
\end{tabular}

